\title{
Cardiovascular status in asymptomatic alcoholics, with reference to the level of ethanol consumption $\star$
}

\author{
MASAYA KINO, HIROYUKI IMAMITCHI *, MASATOMO MORIGUTCHI, KEISHIRO \\ KAWAMURA, TADASU TAKATSU
}

From the Third Division, Department of Internal Medicine, Osaka Medical College, Takatsuki City, Osaka, and the Department of Psychiatry, Ranryoen Hospital, ^ Ibaraki City, Osaka, fapan

SUMMARY One hundred and forty-five alcoholics without known causes of heart disease, who were serially admitted to the alcohol detoxification centre, were studied to see the incidence of cardiac abnormalities and dose related effects of ethanol. All patients were divided into heavy (consumed more than the equivalent amount of $125 \mathrm{ml}$ of pure ethanol daily for 10 years or more) and moderate drinkers (consumed 75 to $125 \mathrm{ml}$ of ethanol daily). All of them were ambulatory and free from cardiac symptoms. There was no difference among heavy and moderate drinkers in the incidence of abnormalities detected by the electrocardiograms and chest $x$-ray films. In the alcoholics, the most frequent finding was a prolonged QTc interval of more than $0.44 \mathrm{~s}$ on the electrocardiogram (62 patients, $42 \cdot 8 \%$ ), unrelated to serum electrolytes imbalance. Cardiomegaly on chest $x$-ray film was observed in 25 patients $(17 \cdot 2 \%)$. M-mode echocardiogram was recorded in randomly selected patients and compared with age and sex matched controls. The interventricular septum and posterior wall were thicker in alcoholics, while left ventricular volume showed no difference. Left ventricular muscle mass was significantly increased only in heavy drinkers. Left ventricular function at rest was not depressed in these patients at an average of 31 days after the last drink of ethanol. Severe heart failure was not found even among the group of heavy drinkers, of whom more than $90 \%$ had liver dysfunction. Cardiac hypertrophy seems to occur in heavy drinkers, but is clinically well compensated in the majority of alcoholics.

Chronic and heavy consumption of ethanol has been said to have deleterious effects upon the cardiovascular system, causing cardiomegaly and severe heart failure. ${ }^{12}$ Inability to reproduce human alcoholic cardiomyopathy in the experimental animal, however, and its rare incidence among chronic alcoholics made us wonder whether ethanol was the sole cause of the disease. ${ }^{13}$ Moreover, most of the clinical observations were based on selected patients with severe heart failure; the majority of asymptomatic alcoholics were not well studied. ${ }^{4}{ }^{5}$ If ethanol is the real cause of alcoholic cardiomyopathy, one can expect latent cardiac abnormalities according to the level of ethanol consumption. To the best of our knowledge, however, the evidence of dose related effects of ethanol is still scarce. ${ }^{67}$

The purpose of this study is to evaluate the dose related effects of ethanol according to the estimated

\footnotetext{
* This study was supported in part by a Grant-in-Aid for Scientific Research from the Japanese Ministry of Education, Science and Culture, and from the Jinsenkai Alumni Research Fund, Osaka Medical College, Osaka, Japan. Received for publication 13 April 1981
}

consumption of pure ethyl alcohol, and to examine the frequency of cardiac abnormalities seen in chronic alcoholics who were serially admitted to the alcohol detoxification centre.

\section{Patients and methods}

One hundred and seventy-eight male patients were studied from March 1979 to October 1979 at the Ranryoen Hospital, which is a major referral centre of Osaka, Kobe and Kyoto, Japan. All patients showed physical and mental dependence on ethyl alcohol and fulfilled the WHO criteria of chronic alcoholism. ${ }^{8}$ All patients had consumed at least the equivalent amount of $75 \mathrm{ml}$ pure ethanol daily for five years until the day before admission. They were ambulatory and free from symptoms of cardiovascular disease. The patients' histories were obtained, especially the amount and duration of alcohol consumption, previous illness, and symptoms of cardiac diseases. Blood samples were drawn for the determination of complete blood count, serum electrolytes, liver 
enzymes, and other relevant blood chemistries. To minimise influences other than alcohol, 33 of 178 patients, 11 with diabetes mellitus, 21 with blood pressure of more than $160 / 90 \mathrm{mmHg}$, two with hypertrophic obstructive cardiomyopathy (HOCM), and one with mitral stenosis, were excluded from this study. To see whether the effects of ethanol are dose dependent, the remaining 145 patients were divided into two groups according to the degree of ethanol consumption (age range 23 to 64 years, mean 44); (1) heavy drinkers $(\mathrm{N}=85)$, consuming more than the equivalent amount of $125 \mathrm{ml}$ pure ethanol daily for at least 10 years; (2) moderate drinkers $(\mathrm{N}=60)$, consuming 75 to $125 \mathrm{ml}$ pure ethanol daily. The clinical diagnosis of the state of the liver was arbitrarily made as follows: fatty liver, hepatomegaly and increase of serum aspartate aminotransferase (AST) or gamma glutamyl transpeptidase ( $\gamma$-GTP) without symptoms; alcoholic hepatitis, abnormal AST and $\gamma$-GTP, with the presence of three or more of the following physical findings: tender hepatomegaly, palmar erythema, spider angiomata, and gynaecomastia; liver cirrhosis, signs of portal hypertension, namely splenomegaly, ascites, and evidence of collateral portal systemic venous circulation. ${ }^{9}$

On reviewing 12 lead electrocardiographic tracings, special care was taken to detect abnormal $Q$ wave, conduction abnormalities including atrioventricular block and bundle-branch blocks, arrhythmias, ST, T wave changes, and QT intervals. Left ventricular hypertrophy was considered to be present when one of the following voltage criteria was fulfilled: $\mathrm{SV} 1+\mathrm{RV} 5 \geqslant 35 \mathrm{~mm}, \mathrm{R}$ in $\mathrm{aVL} \geqslant 11 \mathrm{~mm}, \mathrm{R}$ in V5 or $\mathrm{V} 6 \geqslant 26 \mathrm{~mm} .{ }^{10}$ The QT interval was corrected for the heart rate according to the Bazzett formula as $\mathrm{QT} c=\mathrm{QT} / \sqrt{ } \mathrm{R}-\mathrm{R}$. Chest $x$-ray films were reviewed in all patients and the cardiothoracic ratio was calculated. Echocardiograms were obtained by the standard methods in 34 randomly selected patients (22 heavy drinkers and 12 moderate drinkers) in the supine position, with an $80^{\circ}$ phased array electronic sector scanner with 32 elements (Hitachi EUB-10A), using a $2.3 \mathrm{MHz}$ transducer, placed in the third or fourth intercostal space. Echocardiographic examination was performed at least seven days after admission, at an average of 31 days after the last drink to exclude the acute and withdrawal effects of ethanol. Watching cardiac motion in a two-dimensional long axis image, the $M$-mode echocardiogram was displayed on a fibreoptic recorder (Honeywell model 1219) at a speed of $50 \mathrm{~mm} / \mathrm{s}$, with simultaneous electrocardiogram carotid pulse, and phonocardiogram. No patient showed paradoxical septal motion or apparent asynergy. Echocardiographic measurements were made according to the recommendation by the committee on $\mathrm{M}$-mode standard- ization of the American Society of Echocardiography ${ }^{11}$ as shown in Fig. 1. Left ventricular ejection time was obtained from the carotid pulse tracing. All ultrasonic measurements were made during a consecutive four to five cardiac cycles, with breath held at end-expiration. Left ventricular volumes at end-diastole and end-systole were calculated according to the method of Teichholz et al. ${ }^{12}$ as $V=(7 \cdot 0 / 2 \cdot 4+D)\left(D^{3}\right)$, where $V=$ volume and $D=$ the internal dimensions of the left ventricle at both end-diastole and end-systole. Ejection fraction, mean velocity of circumferential fibre shortening (mean Vcf), ${ }^{13}$ cardiac output, and systemic vascular resistance were also calculated by the standard formulae. Left ventricular mass was estimated by the method of Devereux and Reichek, ${ }^{14}$ where the measurements of end-diastolic diameter (Ddp) included the endocardial echoes of the interventricular septum and the posterior wall, and the measurements of the interventricular septum (IVSp) and posterior wall (PWTp) excluded the endocardial and epicardial echoes as left ventricular mass $=1.04 x\left\{(D d p+P W T p+I V S p)^{3}-(D d p)^{3}\right\}-13.6 g$ (Fig. 2). Thirteen age and sex matched healthy controls were also studied by echocardiography. They were employees at the Ranryoen Hospital, all of whom were proved to be healthy by the annual physical check-up with chest $x$-ray film and electrocardiography. Results from this group were regarded as the basis for comparison. While measuring the echocardiographic tracings, special care was taken to try to exclude the examiner's bias by examining all tracings at the time of completion of this study without knowing the name and age of the particular person.

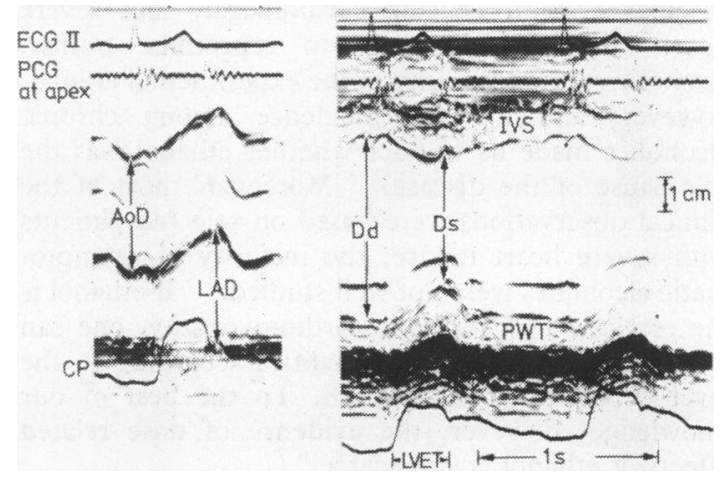

Fig. 1 Points and timing of echocardiographic measurements are shown. CP, carotid pulse tracing; $A o D$, width of the aortic root; $L A D$, left atrial dimension; $D d$, left ventricular dimension at end-diastole; Ds, left ventricular dimension at end-systole; IVS, septal thickness; PWT, posterior wall thickness; LVET, left ventricular ejection time. 


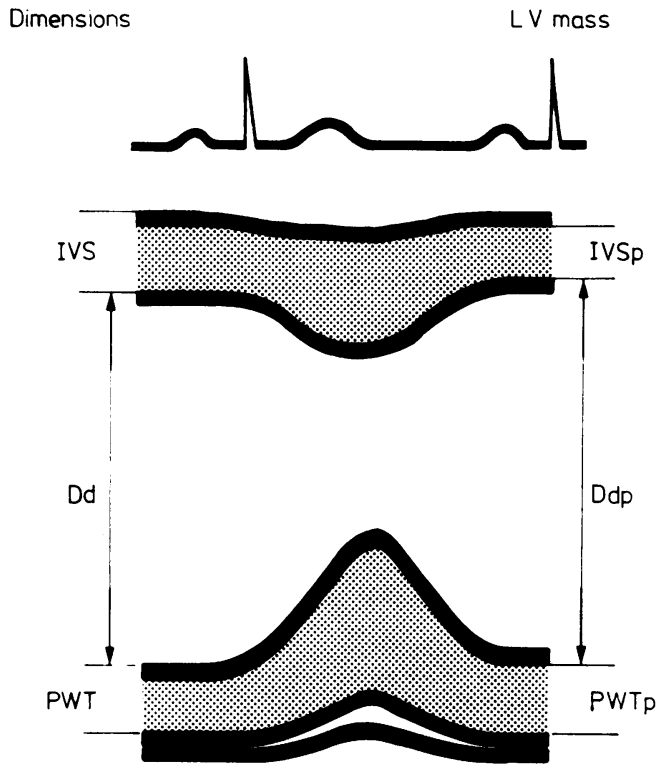

Fig. 2 Methods of measurements for dimensions and left ventricular muscle mass are shown.

Statistical analyses of these data were based on a method of multiple comparison by Tukey in parameters showing homogeneity of variance by Bartlett's method, or a method of Welchi in parameters of inhomogeneity of variance. The comparison of the incidence of abnormalities in the two groups of alcoholics was based on the $\chi^{2}$ test with Yates's correction or Fisher's exact test.

\section{Results}

Patients (Table 1, 2)

No patient had palpitation, dyspnoea, chest pain, or other symptoms suggestive of heart disease at the time of examination. The incidence of hepatic dysfunction was similar in heavy or moderate drinkers (Table 1). One hundred and seven $(73.8 \%)$ patients had fatty liver and $23(15.9 \%)$ had alcoholic hepatitis. One patient had Laennec's liver cirrhosis $(0 \cdot 7 \%)$. Normal
Table 2 Laboratory findings in chronic alcoholics

\begin{tabular}{|c|c|c|c|}
\hline & $\begin{array}{l}\text { Heavy } \\
\text { drinkers } \\
(N=85)\end{array}$ & $\begin{array}{l}\text { Moderate } \\
\text { drinkers } \\
(N=60)\end{array}$ & $\begin{array}{l}\text { Normal } \\
\text { values }\end{array}$ \\
\hline $\mathrm{Hb}(\mathrm{g} / \mathrm{dl})$ & $\begin{array}{l}14 \cdot 4 \pm 1 \cdot 9 \\
(81)\end{array}$ & $\begin{array}{l}14 \cdot 9 \pm 2 \cdot 0 \\
(57)\end{array}$ & $14 \cdot 0 \sim 18 \cdot 0$ \\
\hline $\begin{array}{l}\text { Haematocrit } \\
(\%)\end{array}$ & $\begin{array}{l}40 \cdot 6 \pm 4 \cdot 1 \\
(81)\end{array}$ & $\begin{array}{l}42 \cdot 3 \pm 4 \cdot 2 \\
\quad(57)\end{array}$ & $40 \cdot 0 \sim 50 \cdot 0$ \\
\hline Serum $\mathrm{K}(\mathrm{mmol} / \mathrm{l})$ & $\begin{array}{l}3 \cdot 85 \pm 0 \cdot 50 \\
(84)\end{array}$ & $\begin{array}{l}3 \cdot 88 \pm 0 \cdot 47 \\
(60)\end{array}$ & $3 \cdot 6 \sim 5 \cdot 0$ \\
\hline Serum $\mathrm{Ca}(\mathrm{mmol} / \mathrm{l})$ & $\begin{array}{l}2 \cdot 2 \pm 0 \cdot 2 \\
(82)\end{array}$ & $\begin{array}{l}2 \cdot 2 \pm 0 \cdot 1 \\
(57)\end{array}$ & $2 \cdot 1 \sim 2 \cdot 7$ \\
\hline Serum $\mathrm{Mg}(\mathrm{mmol} / \mathrm{l})$ & $\begin{array}{l}0 \cdot 8 \pm 0 \cdot 2 \\
(84)\end{array}$ & $\begin{array}{l}0.8 \pm 0.1 \\
(59)\end{array}$ & $0 \cdot 7 \pm 1 \cdot 2$ \\
\hline $\operatorname{AST}(\mathrm{U} / \mathrm{ml})$ & $\begin{array}{l}72 \cdot 9 \pm 58 \cdot 2 \\
(85)\end{array}$ & $\begin{array}{l}90 \cdot 9 \pm 93 \cdot 9 \\
(60)\end{array}$ & $8 \sim 40$ \\
\hline $\operatorname{ALT}(\mathrm{U} / \mathrm{ml})$ & $\begin{array}{l}39 \cdot 4 \pm 23 \cdot 1 \\
(85)\end{array}$ & $\begin{array}{l}44 \cdot 9 \pm 38 \cdot 4 \\
(60)\end{array}$ & $5 \sim 35$ \\
\hline r-GTP(U/l) & $\begin{array}{c}216 \pm 239 \\
(84)\end{array}$ & $\begin{array}{l}243 \pm 278 \\
(60)\end{array}$ & $0 \sim 60$ \\
\hline $\mathrm{BUN}(\mathrm{mmol} / \mathrm{l})$ & $\begin{array}{l}3 \cdot 4 \pm 1 \cdot 3 \\
(83)\end{array}$ & $\begin{array}{l}3 \cdot 5 \pm 1 \cdot 3 \\
(59)\end{array}$ & $2 \cdot 9 \sim 7 \cdot 1$ \\
\hline $\mathrm{UA}(\mathrm{mmol} / \mathrm{l})$ & $\begin{array}{l}351 \pm 107 \\
(68)\end{array}$ & $\begin{array}{l}309 \pm 119 \\
(52)\end{array}$ & $119 \sim 494$ \\
\hline $\mathrm{Chol}(\mathrm{mmol} / \mathrm{l})$ & $\begin{array}{l}4 \cdot 3 \pm 1 \cdot 5 \\
(85)\end{array}$ & $\begin{array}{l}4 \cdot 4 \pm 1 \cdot 3 \\
(60)\end{array}$ & $3 \cdot 4 \sim 6 \cdot 5$ \\
\hline $\mathrm{TG}(\mathrm{g} / \mathrm{l})$ & $\begin{array}{l}1.45 \pm 0.95 \\
(85)\end{array}$ & $\begin{array}{c}1.51 \pm 0.91 \\
(60)\end{array}$ & $0.35 \sim 1 \cdot 70$ \\
\hline $\operatorname{Alb}(g / l)$ & $\begin{array}{r}42 \pm 6 \\
(75)\end{array}$ & $\begin{array}{c}43 \pm 6 \\
(40)\end{array}$ & $38 \sim 58$ \\
\hline
\end{tabular}

(Mean \pm SD). ( ) numbers of patients measured; UA, serum uric acid; Chol, serum cholesterol; TG, serum triglycerides; Alb, serum albumin; r-GTP, gamma GTP.

liver function test without hepatomegaly was present in 14 patients $(9 \cdot 7 \%)$. No patient had either significant anaemia or hyperlipidaemia at the time of examination (Table 2). Hypokalaemia was noted in 36 of 144 patients studied $(25.0 \%)$, hypocalcaemia was noted in 14 of $139(10 \cdot 1 \%)$, and hypomagnesaemia in 10 of $143(7 \cdot 0 \%)$.

CHEST X-RAY AND ELECTROCARDIOGRAPHIC FINDINGS (Tables 3, 4)

There was no difference between heavy and moderate drinkers in the incidence of abnormalities detected by chest $x$-ray film and electrocardiogram. Cardiomegaly with a cardiothoracic ratio of more than $51 \%$ was

Table 1 Details of 145 chronic alcoholic patients

\begin{tabular}{|c|c|c|c|c|c|}
\hline & Age (y) & * & $\begin{array}{l}\text { Fatty } \\
\text { liver }\end{array}$ & $\begin{array}{l}\text { Alcoholic } \\
\text { hepatitis }\end{array}$ & $\begin{array}{l}\text { Laennec's } \\
\text { liver } \\
\text { cirrhosis }\end{array}$ \\
\hline $\begin{array}{l}\text { Heavy drinkers }(\mathrm{N}=85) \\
\text { Moderate drinkers }(\mathrm{N}=60) \\
\text { Total }(\mathrm{N}=145)\end{array}$ & $\begin{array}{l}45 \cdot 4 \pm 6 \cdot 8 \\
42 \cdot 1 \pm 8 \cdot 8 \\
44 \cdot 0 \pm 7 \cdot 8\end{array}$ & $\begin{array}{r}9(10 \cdot 6 \%) \\
5(8 \cdot 3 \%) \\
14(9 \cdot 7 \%)\end{array}$ & $\begin{array}{r}61(71 \cdot 8 \%) \\
46(76 \cdot 7 \%) \\
107(73 \cdot 8 \%)\end{array}$ & $\begin{array}{r}14(16 \cdot 5 \%) \\
9(15 \cdot 0 \%) \\
23(15 \cdot 9 \%)\end{array}$ & $\begin{array}{l}1(1 \cdot 2 \%) \\
0 \\
1(0 \cdot 7 \%)\end{array}$ \\
\hline
\end{tabular}

* Normal liver function test without hepatomegaly. 
Table 3 Electrocardiographic findings and cardiothoracic ratio in 145 alcoholics

\begin{tabular}{|c|c|c|c|c|}
\hline & $\begin{array}{l}\text { Heavy } \\
\text { drinkers } \\
(N=85)\end{array}$ & $\begin{array}{l}\text { Moderate } \\
\text { drinkers } \\
(N=60)\end{array}$ & & $\begin{array}{l}\text { Total } \\
(N=145)\end{array}$ \\
\hline QTc (s) & $0.43 \pm 0.03$ & $0.43 \pm 0.03$ & NS & $0.43 \pm 0.03$ \\
\hline Prolonged QTc & $31(36 \cdot 5 \%)$ & $31(52 \cdot 5 \%)$ & NS & $62(42 \cdot 8 \%)$ \\
\hline $\begin{array}{l}\text { Left ventricular } \\
\text { hypertrophy }\end{array}$ & $14(16 \cdot 5 \%)$ & $6(10.0 \%)$ & NS & $20(13 \cdot 8 \%)$ \\
\hline $\begin{array}{l}\text { Nonspecific } T \\
\text { wave changes }\end{array}$ & $7(8 \cdot 2 \%)$ & $9(15 \cdot 0 \%)$ & NS & $16(11 \cdot 0 \%)$ \\
\hline $\begin{array}{l}\text { Left axis } \\
\text { deviation }\end{array}$ & $4(4 \cdot 7 \%)$ & $4(6 \cdot 7 \%)$ & NS & $8(5 \cdot 5 \%)$ \\
\hline $\begin{array}{l}\text { Right bundle-branch } \\
\text { block }\end{array}$ & $4(4 \cdot 7 \%)$ & $1(1 \cdot 7 \%)$ & NS & $5(3 \cdot 5 \%)$ \\
\hline PVC & $3(3 \cdot 5 \%)$ & 0 & NS & $3(2 \cdot 1 \%)$ \\
\hline PAC & $2(2 \cdot 4 \%)$ & 0 & NS & $2(1 \cdot 4 \%)$ \\
\hline Atrial fibrillation & $1(1 \cdot 2 \%)$ & 0 & NS & $\mathrm{l}(0 \cdot 7 \%)$ \\
\hline Abnormal Q & $1(1 \cdot 2 \%)$ & 0 & NS & $1(0 \cdot 7 \%)$ \\
\hline $\begin{array}{l}\text { Left atrial } \\
\text { enlargement }\end{array}$ & 0 & $1(1 \cdot 7 \%)$ & NS & $1(0 \cdot 7 \%)$ \\
\hline $\begin{array}{l}\text { Atrioventricular } \\
\text { block }\end{array}$ & 0 & 0 & NS & 0 \\
\hline $\begin{array}{l}\text { Cardiomegaly } \\
\qquad(\mathrm{CTR} \geqslant 51 \%)\end{array}$ & $14(16 \cdot 5 \%)$ & $11(18 \cdot 3 \%)$ & NS & $25(17 \cdot 2 \%)$ \\
\hline
\end{tabular}

PVC, premature ventricular contraction; PAC, premature atrial contraction; NS, not significant; CTR, cardiothoracic ratio.

found in 25 of 145 patients (17-2\%). Prolonged QTc interval of more than $0.44 \mathrm{~s}$ was found in 62 alcoholics $(42 \cdot 8 \%)$. The mean QTc interval of 145 patients was $0.43 \pm 0.03 \mathrm{~s}$ (mean $\pm S D)$. In those with prolonged QTc, serum calcium was $2 \cdot 2 \pm 0.2 \mathrm{mmol} / 1$ $(4.5 \pm 0.3 \mathrm{mEq} / 1)$, serum magnesium was $0.8 \pm 0.2 \mathrm{mmol} / \mathrm{l}(2 \cdot 0 \pm 0.4 \mathrm{~g} / \mathrm{dl})$, and serum potassium was $3.8 \pm 0.5 \mathrm{mmol} / 1$. Left ventricular hypertrophy was found in 20 patients $(13.8 \%)$, while 19 patients fulfilled only the voltage criteria without secondary ST, $T$ wave changes. Nonspecific $T$ wave changes (flat or blunt $\mathrm{T}$ ) were noted in 16 patients $(11.0 \%) ; 12$ of them had blood tests for serum electrolyte determination within 48 hours of the electrocardiographic examination and their serum potassium level was $3.3 \pm 0.5 \mathrm{mmol} / \mathrm{l}$. Nine of 12 patients with the $T$ wave changes $(75.0 \%)$ had hypokalaemia of less than $3.5 \mathrm{mmol} / \mathrm{l}$. In addition, 20 of 36 patients with hypokalaemia $(55 \cdot 6 \%)$ had normal $\mathrm{T}$ wave contour.

Table 4 Electrocardiographic abnormalities and serum electrolytes (mean $\pm S D$ )

\begin{tabular}{llll}
\hline & $K(\mathrm{mmol} / \mathrm{l})$ & $\mathrm{Ca}(\mathrm{mmol} / \mathrm{l})$ & $\mathrm{Mg}(\mathrm{mmol} / \mathrm{l})$ \\
\hline $\begin{array}{l}\text { Nonspecific T wave } \\
\text { changes }(\mathrm{N}=12)\end{array}$ & $3.26 \pm 0.48$ & $2.2 \pm 0.2$ & $0.81 \pm 0.14$ \\
$\begin{array}{l}\text { Prolonged QTc }(>0.44 \mathrm{~s}) \\
(\mathrm{N}=61)\end{array}$ & $3.80 \pm 0.51$ & $2.2 \pm 0.2$ & $0.80 \pm 0.17$ \\
\hline
\end{tabular}

Table 5 Echocardiographic findings (mean $\pm S D$ ) in chronic alcoholics

\begin{tabular}{|c|c|c|c|}
\hline & $\begin{array}{l}\text { Control } \\
(N=13)\end{array}$ & $\begin{array}{l}\text { Moderate } \\
(N=12)\end{array}$ & $\begin{array}{l}\text { Heavy } \\
(N=22)\end{array}$ \\
\hline Age (y) & $43 \cdot 0 \pm 6 \cdot 3$ & $42 \cdot 9 \pm 7 \cdot 6$ & $43 \cdot 4 \pm 5 \cdot 6$ \\
\hline $\operatorname{AoD}\left(\mathrm{cm} / \mathrm{m}^{2}\right)$ & $1.84 \pm 0.28$ & $2 \cdot 03 \pm 0.19$ & $2 \cdot 01 \pm 0.22$ \\
\hline $\mathrm{LAD}\left(\mathrm{cm} / \mathrm{m}^{2}\right)$ & $2 \cdot 17 \pm 0 \cdot 18$ & $2.52 \pm 0.19$ * & $2 \cdot 32 \pm 0.28$ \\
\hline $\operatorname{DDR}(\mathrm{cm} / \mathrm{s})$ & $19.09 \pm 3.65$ & $\begin{array}{c}19 \cdot 86 \pm 9 \cdot 16 \\
(N=4)\end{array}$ & $\begin{array}{c}16 \cdot 34 \pm 5 \cdot 20 \\
(\mathrm{~N}=14)\end{array}$ \\
\hline IVS(cm) & $0.77 \pm 0.14$ & $1.05 \pm 0.20 \star \star$ & $1.03 \pm 0.17 \star \star$ \\
\hline PWT(cm) & $0.89 \pm 0 \cdot 15$ & $1.05 \pm 0.17 \star$ & $1 \cdot 00 \pm 0 \cdot 13$ \\
\hline $\mathrm{mVcf}(\mathrm{circ} / \mathrm{s})$ & $1 \cdot 32 \pm 0.23$ & $\begin{array}{l}1 \cdot 30 \pm 0 \cdot 21 \\
(\mathrm{~N}=4)\end{array}$ & $\begin{array}{l}1 \cdot 27 \pm 0 \cdot 20 \\
(\mathrm{~N}=14)\end{array}$ \\
\hline $\operatorname{EDV}\left(\mathrm{ml} / \mathrm{m}^{2}\right)$ & $88 \cdot 6 \pm 17 \cdot 9$ & $82 \cdot 0 \pm 10 \cdot 1$ & $88 \cdot 7 \pm 17 \cdot 7$ \\
\hline $\mathrm{CI}\left(\mathrm{l} / \mathrm{min} / \mathrm{m}^{2}\right)$ & $4 \cdot 23 \pm 1 \cdot 08$ & $3 \cdot 89 \pm 0 \cdot 72$ & $3.64 \pm 0.93$ \\
\hline $\mathrm{EF}(\%)$ & $69 \cdot 5 \pm 6 \cdot 4$ & $70 \cdot 5 \pm 5 \cdot 8$ & $66 \cdot 5 \pm 9 \cdot 1$ \\
\hline HR(beats/min) & $69 \cdot 4 \pm 11 \cdot 5$ & $64 \cdot 4 \pm 8 \cdot 2$ & $61 \cdot 9 \pm 8 \cdot 7$ \\
\hline $\mathrm{mBP}(\mathrm{mmHg})$ & $92 \cdot 3 \pm 9 \cdot 1$ & $85 \cdot 5 \pm 8 \cdot 3$ & $86 \cdot 6 \pm 9 \cdot 6$ \\
\hline $\begin{array}{l}\text { TSR } \\
\text { (dyne } \mathrm{s} \mathrm{cm}^{-5} \text { ) }\end{array}$ & $1094 \pm 263$ & $1139 \pm 195$ & $1258 \pm 417$ \\
\hline $\operatorname{LVM}\left(g / m^{2}\right)$ & $102 \pm 23$ & $121 \pm 37$ & $132 \pm 28$ * \\
\hline
\end{tabular}

${ }^{\star} \mathrm{p}<0.05{ }^{\star \star} \mathrm{p}<0.01$

LAD, left atrial dimension; DDR, diastolic descent rate; IVS, septal thickness; PWT, posterior wall thickness; EDV, end-diastolic volume; $\mathrm{CI}$, cardiac index; $\mathrm{EF}$, ejection fraction; HR, heart rate; $\infty$ TSR, systemic vascular resistance; LVM, left ventricular mass.

Right bundle-branch block was found in five patients (3.5\%), left axis deviation in eight $(5 \cdot 5 \%)$, premature ventricular contractions in three patients $(2 \cdot 1 \%)$, and premature atrial contractions in two $(1 \cdot 4 \%)$. Atrial fibrillation, left atrial enlargement, and abnormal $Q$ waves in the anteroseptal area were noted in one patient $(0.7 \%)$, respectively. No patient had atrioventricular block or left bundle-branch block.

ECHOCARDIOGRAPHIC FINDINGs (Table 5, Fig. 3) An adequate echocardiographic tracing was available in 13 controls, 12 moderate drinkers, and 22 heavy drinkers. Their mean age was identical (controls, $43.0 \pm 6.3$ years old; moderate drinkers, $42.9 \pm 7 \cdot 6$; heavy drinkers, $43 \cdot 4 \pm 5 \cdot 6$, mean $\pm S D$ ). The interventricular septum in both alcoholic groups was thicker than that in the controls (controls, $0.77 \pm 0.14 \mathrm{~cm}$; moderates, $1.05 \pm 0.20, \mathrm{p}<0.01$; heavy, $1.03 \pm 0 \cdot 17, \mathrm{p}<0.01)$. The posterior wall in moderate drinkers was thicker than that in controls (control, $0.89 \pm 0.15 \mathrm{~cm}$; moderate, $1.05 \pm 0.17$, $\mathrm{p}<0.05$; heavy, $1.00 \pm 0.13$, NS). Left ventricular end-diastolic volume was identical in all three groups. Left ventricular muscle mass in both alcoholics was greater than that in controls, but only the heavy drinkers reached statistical significance (controls, $102 \pm 23 \mathrm{~g} / \mathrm{m}^{2}$; moderate $121 \pm 37$, NS; heavy, $132 \pm 28, \mathrm{p}<0.05)$. Cardiac output, ejection fraction, mean Vcf, and diastolic descent rate of the anterior mitral leaflet had tendencies to be reduced in alcoholics but without statistical significance. Mean 

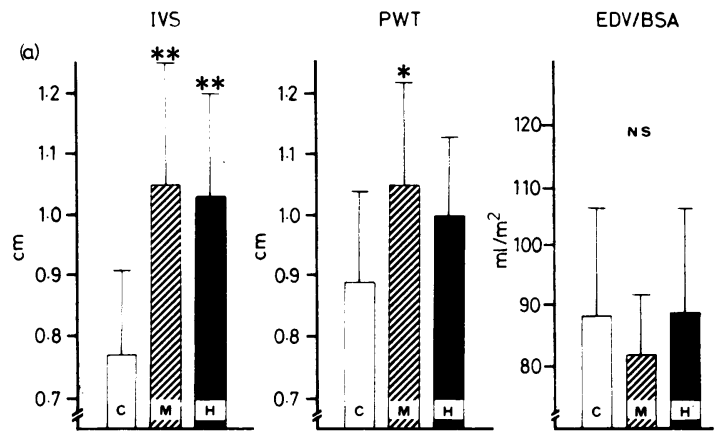

(b)
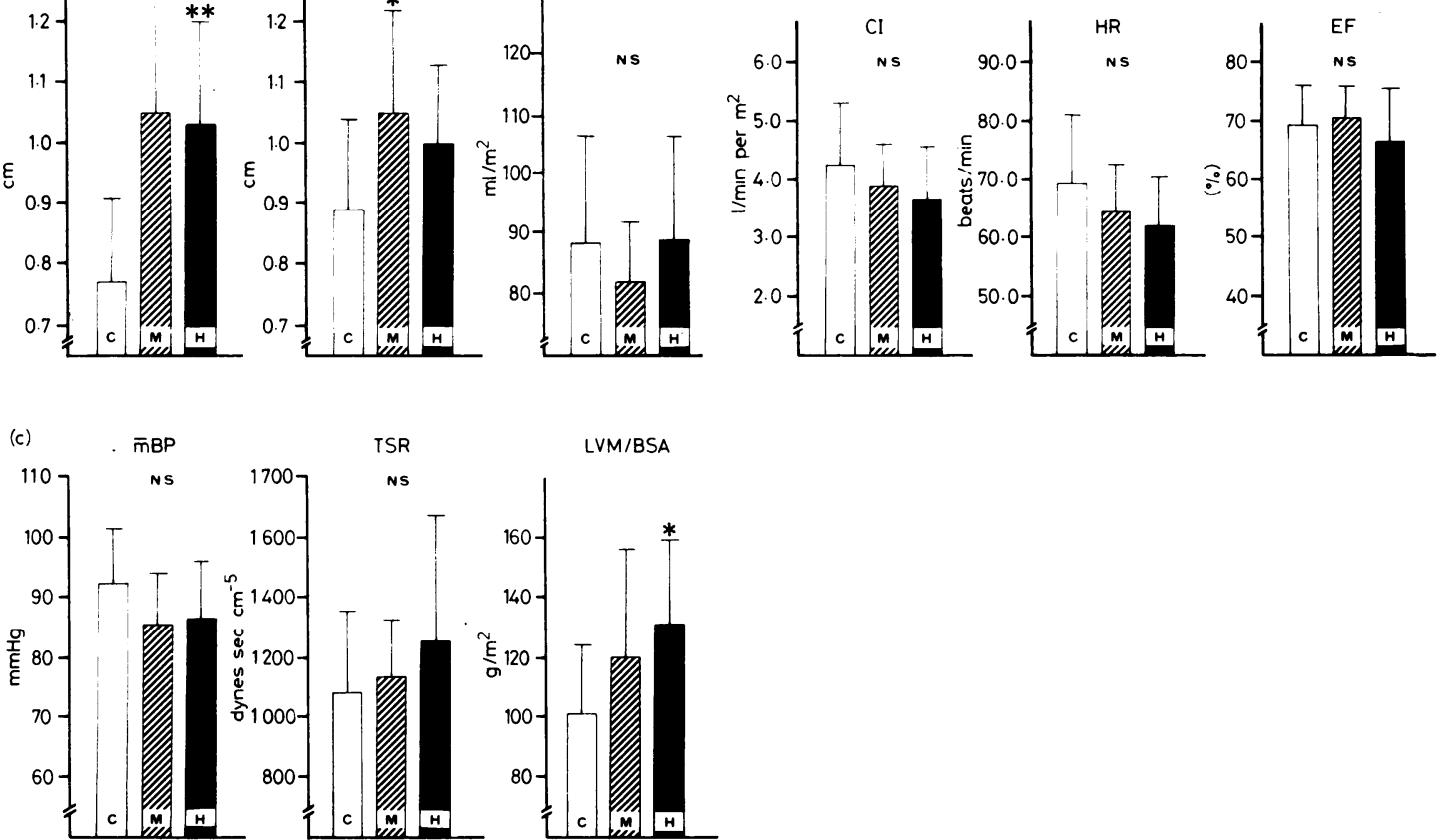

Fig. 3 Septal and posterior wall thicknesses were increased in alcoholics while left ventricular volume remained unchanged. $C$, controls $(N=13) ; M$, moderate drinkers $(N=12) ; H$, heavy drinkers $(N=22) ; I V S$, septal thickness; $P W T$, posterior wall thickness; $B S A$, body surface area; NS, not significant. Mean and standard deviation are shown. ${ }^{\star} p<0 \cdot 05, \star \star p<0 \cdot 01$. (b) Cardiac output, heart rate, and ejection fraction were identical in all three groups. CI, cardiac index; HR, heart rate; EF, ejection fraction. (c) Left ventricular muscle mass was increased in heavy drinkers only. Mean blood pressure and systemic vascular resistance were similar. mBP, mean blood pressure; TSR, systemic vascular resistance; $L V M$, left ventricular muscle mass; BSA, body surface area. $\star p<0.05, N S$, not significant.

blood pressure was lower and heart rate slower in alcoholics, though these were not statistically significant.

\section{Discussion}

Prolonged QTc interval was the most frequent electrocardiographic finding, seen in $43 \%$ of the alcoholics. All patients had an electrocardiogram at least seven days after their last drink, so that the acute effects of ethanol were excluded. The high incidence of QTc prolongation in alcoholics, reported by previous investigators, ${ }^{1516}$ is comparable to the present study. Though neither mean serum calcium nor magnesium was low in these patients, alcohol was found to impair calcium uptake and binding by sarcoplasmic reticulum in the experimental study. ${ }^{17}$ Prolonged QTc interval, therefore, may be a reflection of such metabolic and electrical alterations in the chronic alcoholic. A recent electophysio- logical study in alcoholic cardiomyopathy by Luca $^{18}$ also substantiates our results, showing prolonged right ventricular monophasic action potential duration, especially prolongation of phase 3 . Since phase 3 of the action potential associates with the increased outward flow of $\mathrm{K}^{+}$, an alternative explanation would be the high prevalence of hypokalaemia in this population. This fact may also explain the $T$ wave abnormality. Evans ${ }^{19}$ described dimpled, cloven, and spinous $T$ waves in alcoholic cardiomyopathy, but these $T$ wave abnormalities seem neither frequent nor specific to alcoholics. ${ }^{16} \mathrm{~T}$ wave changes as such were also found in this study but only $11 \cdot 0 \%$. Moreover, $75 \%$ of these $\mathrm{T}$ wave changes were associated with hypokalaemia of less than $3.5 \mathrm{mmol} / \mathrm{l}$. Thus, rare incidence of $T$ wave changes and its frequent association with hypokalaemia are considered to be in opposition to, or even denying, the toxic effects of alcohol for these $T$ wave abnormalities. Left ventricular hypertrophy was 
present in the electrocardiogram in $13.8 \%$. Cardiomegaly was found on the chest $x$-ray film in $17 \cdot 2 \%$ of the patients.

The cardinal finding in this report is increased left ventricular muscle mass detected by echocardiography even in asymptomatic alcoholics who had consumed more than $125 \mathrm{ml}$ pure ethanol daily for 10 years or more. This agrees with the report by Askanas et al. ${ }^{6}$ who studied the effects of ethanol in heavy drinkers consuming approximately $160 \mathrm{ml}$ ethanol daily for five years or more. It is of interest, however, that alcoholics who had consumed less than $125 \mathrm{ml}$ ethanol had smaller heart weights than heavy drinkers. Thus, left ventricular muscle mass seems to be increased according to the level of ethanol consumption. Normal controls had a left ventricular muscle mass of $102 \mathrm{~g} / \mathrm{m}^{2}$, which is comparable to that reported for normal men by Kennedy et al. ${ }^{20}$ who had shown normal heart weights to be $99 \mathrm{~g} / \mathrm{m}^{2}$ by the angiographic method. Since the left ventricular volume was identical in controls and alcoholics, this increase of left ventricular muscle mass in alcoholics may have been the result of relatively increased thickness of the interventricular septum and the left ventricular free wall. Postmortem studies of alcoholics by Schenk and Cohen ${ }^{21}$ and Hognestad and Teisberg ${ }^{22}$ showed that cellular infiltrate, hypertrophy, and fibrosis were the frequent findings in chronic alcoholics. Since alcohol has direct toxic effects on the heart, ${ }^{17}$ the hypertrophy seen in alcoholics may be the result of a chronic process of degeneration and repair going on in the heart. Tobin et al. $^{2}$ described three stages of alcoholic heart disease: stage I without cardiomegaly but with minimal symptoms, stage II predominantly with left ventricular enlargement, and stage III with a much enlarged and dilated heart. Alcoholics in the present study may fall into stage I or between stages I and II by Tobin's classification and are considered to be compensated by the increased left ventricular muscle mass.

Spodick et al. ${ }^{23}$ found cardiac dysfunction in asymptomatic ambulatory alcoholics who were examined within 72 hours after their last drink. Askanas et al. ${ }^{6}$ described increased left ventricular muscle mass as well as abnormal systolic time intervals in alcoholics who were examined three to six days after drinking and concluded that there was decreased myocardial compliance in these patients. Reeves $e t$ al..$^{24}$ found normal left ventricular function in chronic asymptomatic alcoholics after a long period of abstinence from ethanol (mean duration of abstinence was 3.1 years). In the present study, the cardiac function of the alcoholics may be considered to be at the recovery stage compensated with the increased left ventricular muscle mass. An association of a heavy consumption of ethanol with increased left ventricular muscle mass and probably with myocardial degeneration may well reflect an early stage of serious cardiomyopathy. Rare incidence of congestive heart failure even among the patients consuming the equivalent dose of ethanol to that of patients with alcoholic cardiomyopathy ${ }^{2} 7$ leaves a possibility, however, that still unidentified additional factors play a role in the pathogenesis of alcoholic cardiomyopathy.

The authors thank Mr Shunitsu Hatanaka and Dr Masashi Goto, Shionogi Statistical Centre, Osaka, for or their assistance in the statistical analyses, and $\mathrm{Dr}$ C Walter H Abelmann, Harvard Medical School, 을 Boston, Massachusetts, and Dr David H Spodick, $\overrightarrow{-}$ University of Massachusetts Medical School, Z Worcester, Massachusetts, for their advice during the preparation of this manuscript. Invaluable criticisms and suggestions were provided by Yuzo Hirota and $\Phi$ Yoshinori Doi, The Third Division, Department of Internal Medicine, Osaka Medical College.

\section{References}

1 Abelmann WH, Ramirez A. Alcoholic cardiovascular disease. In: Rothschild MA, Oratz M, Schreiber SS, eds.Alcohol and abnormal protein biosynthesis. Biochemical and clinical. New York: Pergamon Press, 1975; 459-72.

2 Tobin JR Jr, Driscoll JF, Lim MT, Sutton GC, Szanto PB, Gunnar RM. Primary myocardial disease and alcoholism. The clinical manifestations and course of the disease in a selected population of patients observed for three or more years. Circulation 1967; 35: 754-64.

3 Härtel G, Louhija A, Konttinen A. Cardiovascular study of 100 chronic alcoholics. Acta Med Scand 1969; 185: 507-13.

4 Alexander CS. Idiopathic heart disease. I. Analysis of 100 cases, with special reference to chronic alcoholism. Am f Med 1966; 41: 213-28.

5 Regan TJ, Levinson GE, Oldewurtel HA, Frank MJ, Weisse AB, Moschos CB. Ventricular function in noncardiacs with alcoholic fatty liver: role of ethanol in the production of cardiomyopathy. $\mathcal{F}$ Clin Invest 1969; 48: $397-407$.

6 Askanas A, Udoshi M, Sadjadi SA. The heart in chronic alcoholism: a noninvasive study. Am Heart $\mathcal{F}$ 1980; 99: 9-16.

7 Koide $T$, Ozeki $K$. The incidence of myocardial abnormalities in man related to the level of ethanol consumption. A proposal of a diagnostic criterion of alcoholic cardiomyopathy. $\mathcal{F} n$ Heart $\mathcal{F} 1974$; 15: 337-48.

8 World Health Organization, Expert Committee on Mental Health. Alcohol Subcommittee Second Report. WHO Tech Rep Ser 1952; 48.

9 Rankin JGD, Orrego-Matte H, Deschênes J, Medline A, Findlay JE, Armstrong AIM. Alcoholic liver disease: the problem of diagnosis. Alcoholism 1978; 2: 327-38. 
10 Sokolow M, Lyon TP. The ventricular complex in left ventricular hypertrophy as obtained by unipolar precordial and limb leads. Am Heart $f$ 1949; 37: 161-86.

11 Sahn DJ, DeMaria A, Kisslo J, Weyman A. (The committee on M-mode standardizations.) Recommendations regarding quantitation in $\mathrm{M}$-mode echocardiography: results of a survey of echocardiographic measurements. Circulation 1978; 58: 1072-83.

12 Teichholz LE, Kreulen T, Herman MV, Gorlin R. Problems in echocardiographic volume determinations: echocardiographic-angiographic correlations in the presence or absence of asynergy. Am $\mathcal{F}$ Cardiol 1976; 37: 7-11.

13 Cooper RH, O'Rourke RA, Karliner JS, Peterson KL, Leopold GR. Comparison of ultrasound and cineangiographic measurements of the mean rate of circumferential fiber shortening in man. Circulation 1972; 46: 914-23.

14 Devereux RB, Reichek N. Echocardiographic determination of left ventricular mass in man. Anatomic validation of the method. Circulation 1977; 55: 613-8.

15 Burch GE, Giles TD. Alcoholic cardiomyopathy. Concept of the disease and its treatment. Am $\mathcal{F}$ Med 1971; 50: 141-5.

16 Koide T, Machida K, Nakanishi A, Ozeki K, Mashima $\mathrm{S}$, Kono $\mathrm{H}$. Cardiac abnormalities in chronic alcoholism. An evidence suggesting association of myocardial abnormality with chronic alcoholism in 107 Japanese patients admitted to a psychiatric ward. $\mathcal{F p n ~ H e a r t ~} \mathcal{F}$ 1972; 13: 418-27.
17 Bing RJ. Cardiac metabolism. Its contributions to alcoholic heart disease and myocardial failure. Circulation 1978; 58: 965-70.

18 Luca C. Electrophysiological properties of right heart and atrioventricular conducting system in patients with acoholic cardiomyopathy. Br Heart $\mathcal{F} 1979$; 42: 274-81.

19 Evans W. The electrocardiogram of alcoholic cardiomyopathy. Bri Heart $\mathcal{F}$ 1959; 21 : 445-56.

20 Kennedy JW, Baxley WA, Figley MM, Dodge HT, Blackmon JR. Quantitative angiocardiography. I. The normal left ventricle in man. Circulation 1966; 34: 272-8.

21 Schenk EA, Cohen J. The heart in chronic alcoholism. Pathologia et Microbiologia 1970; 35: 96-104.

22 Hognestad J. Teisberg P. Heart pathology in chronic alcoholism. Acta Path Microbiol Scand [A] 1973; 81: 315-22.

23 Spodick DH, Pigott VM, Chirife R. Preclinical cardiac malfunction in chronic alcoholism. Comparison with matched normal controls with alcoholic cardiomyopathy. N Engl f Med 1972; 287: 677-80.

24 Reeves WC, Nanda NC, Gramiak R. Echocardiography in chronic alcoholics following prolonged periods of abstinence. Am Heart $\mathcal{F}$ 1978; 95: 578-83.

Requests for reprints to Dr Masaya Kino, The Third Division, Department of Internal Medicine, Osaka Medical College, 2-7 Daigaku-cho, Takatsuki City, Osaka, Japan 569. 